\title{
ENTREVISTA COM HAIGANUCH SARIAN: REFLEXÕES SOBRE O MUNDO GREGO E O ANTIGO ORIENTE PRÓXIMO
}

\begin{abstract}
Palavras-chave
Arqueologia Clássica; Museu de Arqueologia e Etnologia - Universidade de São Paulo; Escola Francesa de Atenas; Mundo grego; Antigo Oriente Próximo.
\end{abstract}

\section{Keywords}

Classical Archaeology; Museum of Archaeology and Ethnology University of São Paulo; French School at Athens; Greek World; Ancient Near East.

O texto que segue é uma transcrição com pequenas modificações de uma entrevista oral concedida pela professora Haiganuch Sarian nos dias 22 de novembro e 14 de dezembro de 2016, realizada nas dependências do Museu de Arqueologia e Etnologia da Universidade de São Paulo (MAEUSP) à revista Heródoto, tendo como entrevistador Gilberto da Silva Francisco.

A professora Sarian é uma das mais importantes pesquisadoras em Arqueologia do Mediterrâneo Antigo no Brasil e com ampla inserção internacional. No Brasil, atuou fortemente na formação de pessoal em campos variados, apresentando cursos de graduação e pós-graduação, extensão universitária; além de ter convidado uma série de especialistas como Paul Courbin, François Lissarrague, Roland Étienne, Annie Bélis, Dominique Mulliez, Marie Françoise Billot, Phillipe Bruneau, entre outros, para apresentarem cursos e (ou) palestras na Universidade de São Paulo.

No campo da pós-graduação, orientou muitas pesquisas no Departamento de Antropologia da FFLCH-USP e no MAE-USP, cobrindo campos da arqueologia grega, romana, mas também estudos etruscos e egiptologia, entre outros. Vários de seus ex-orientandos ocupam cargos em universidades públicas brasileiras, como a USP, Unicamp, UFPel, 
UFRJ, UFBA e Unifesp. Quanto à sua atuação internacional, ela é autora de verbetes de obras de referência como o LIMC (Lexicon Iconographicum Mythologiae Classicae) e o ThesCRA (Thesaurus Cultus et Rituum Antiquorum), e é responsável pelas pesquisas arqueológicas relacionadas ao Santuário de Hera em Delos, dossiê de pesquisa que lhe foi atribuído pela Escola Francesa de Atenas (École Française d'Athènes, EFA), instituição onde é atualmente membro sênior.

Os temas tratados na entrevista são, portanto, relacionados a aspectos detidos de sua pesquisa, que é mais ampla, coerentes com o tema principal da revista Heródoto: o mundo clássico e suas conexões afroasiáticas. As questões foram elaboradas por Gilberto da Silva Francisco, editor desta revista, e enviadas com antecedência à entrevistada. A transcrição foi feita por um grupo de alunos que gentilmente aceitaram colaborar com a revista, são eles Diego Henrique Pires (PUC-Campinas), Erik de Lima Correia, Jemima Novaes Siqueira e Kelly Freire Delmondes (Unifesp), aos quais agradecemos profundamente pela colaboração.

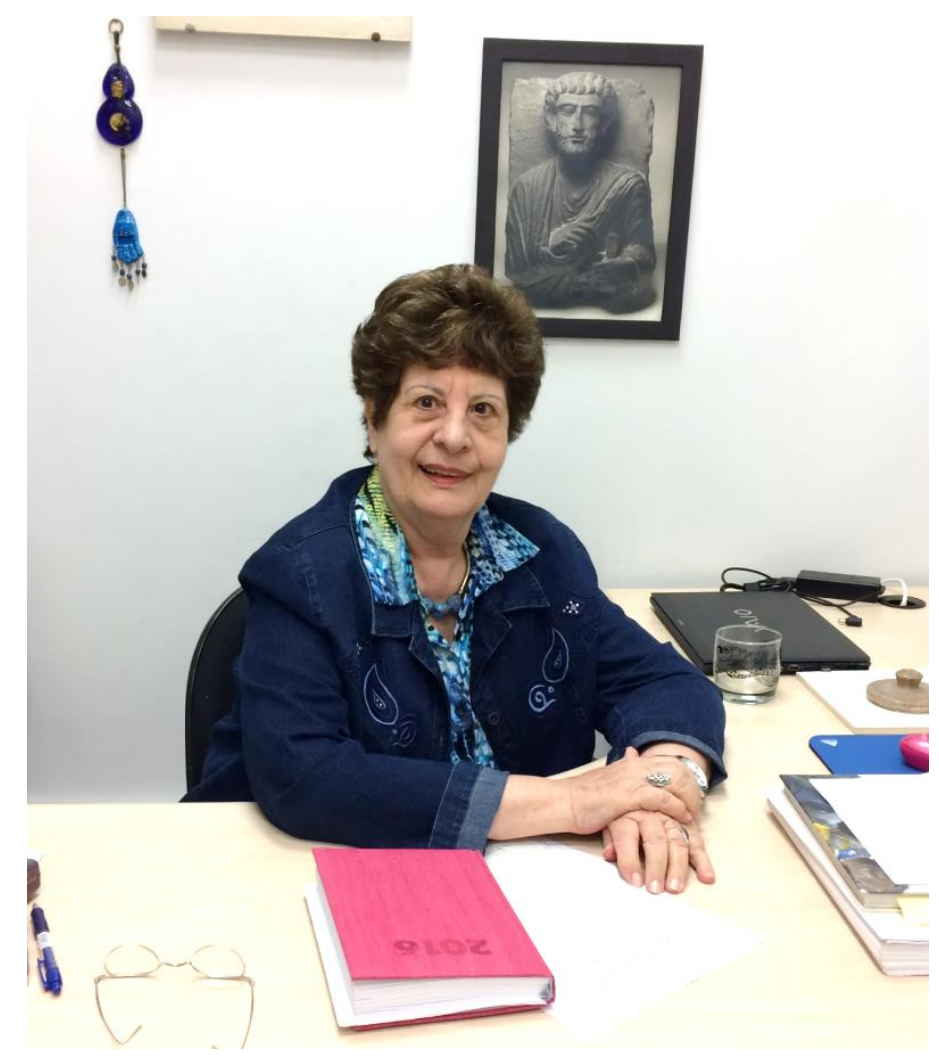

Fig. 1. Professora Haiganuch Sarian em sua sala no MAE-USP. Acima, à direita, foto do relevo funerário de Palmira. 
HAIGANUCH SARIAN (H.S.): Eu agradeço o seu convite para me entrevistar, mas antes de atender às questões específicas, desejo fazer uma pequena introdução. Em primeiro lugar, me apresentar. Sou a professora Haiganuch Sarian, atualmente aposentada, mas professora sênior do Museu de Arqueologia e Etnologia e professora efetiva do Programa de Pós-graduação em Arqueologia desse museu.

Muitas de suas questões se referem ao acervo do MAE, acervo mediterrânico e médio-oriental, e eu queria adiantar que, quando entrei no museu, prestei um concurso que, na época, era um concurso de efetivação; e, no programa do concurso, foi colocada uma lista de temas que incluíam todo o acervo do MAE, acervo mediterrânico antigo, desde o neolítico até o período bizantino. Fui obrigada a estudar muito esse material, eu não o conhecia. Acabava de chegar da Escola Francesa de Atenas, depois de 4 anos de pesquisas na França onde me doutorei (Caen e Paris) e de 2 anos na EFA, especializando-me em cerâmica e iconografia, de modo que tive que estudar assuntos, objetos e peças muitos diferentes pela primeira vez. Então, isso justifica meu interesse pelo tratamento cientifico de boa parte do acervo.

Outro assunto, e que permeia duas publicações minhas, é o meu interesse por Chipre. Quando eu estava ainda na Escola Francesa de Atenas, e já sabendo que eu viria para o MAE, que na época era MAA (Museu de Arte e Arqueologia), o diretor e professor Ulpiano Bezerra de Menezes ${ }^{1}$ me pediu que estudasse os vasos cipriotas que tinham acabado de chegar ao museu por uma compra feita pelo professor Eurípedes ${ }^{2}$ junto ao Serviço de Antiguidades de Nicósia. E, então, eu preparei um pequeno catálogo dessas peças, no total eram uma peça do período neolítico, um machado, uma lamparina arcaica, e 11 vasos, datados do Bronze Antigo até o Período Romano. Preparei esse pequeno catálogo e tive que me introduzir na bibliografia cipriota. Praticamente, o catálogo foi feito na biblioteca da Escola Francesa. O Ulpiano me mandou a lista das peças, as fotos, e uma pequena descrição e, com base nisso, eu fiz a pesquisa bibliográfica, definindo a cronologia e redigindo o artigo.

Outro envolvimento com o Oriente Próximo e Médio são algumas viagens que fiz a essas regiões. Eu fui à Turquia em 1973, quando houve o Congresso Internacional de Arqueologia Clássica em Ancara. Viajei pela região e, antes de participar das escavações na Síria, eu já tinha feito duas viagens à Síria e ao Líbano, por conta de contatos com parentes meus do

\footnotetext{
1 Professor emérito da FFLCH-USP. Foi diretor do MAE-USP, do Instituto de Pré-História-USP e do Museu Paulista-USP.

2 Professor Eurípedes Simões de Paula, professor de História Antiga da FFLCH-USP, onde foi diretor, e um dos fundadores do antigo MAA, do qual foi também o primeiro diretor.
} 
lado da minha mãe que moram em Beirute; e eu tinha também uma tia na Síria, em Kessab. E a terceira viagem foi por ocasião das escavações do professor Paul Courbin, sobre as quais falaremos mais adiante.

E, além desses motivos, há outro que explica a minha atenção ao Oriente Próximo e ao Levante, ao litoral levantino, com relação à Grécia: são as minhas origens. De um lado, por parte de pai, sou descendente de armênios, mas armênios da Cilícia, da região da Turquia que teve muito contato com a Grécia, principalmente Tarso e Al Mina; por outro lado, por parte da minha mãe, sou descendente de assírios, coisa que quase ninguém sabe. Por causa do meu nome, sempre pensam em armênios, mas minha mãe nasceu em Urfa (atual Turquia, antiga cidade assíria da Alta Mesopotâmia, Edessa no Período Helenístico). Urfa era quase inteiramente povoada por esses descendentes de assírios que se assimilaram aos armênios da região, por isso a língua da minha mãe também era o armênio. Mas, o nome e sobrenome da minha mãe não são armênios, Behie Bessos. Quase ninguém conhece essa história, e a única pessoa que realmente entendeu essa minha ligação com o grupo dos assírios que viveu em Urfa foi a professora Helène Cassin, assirióloga, e ela ficou muito interessada em conhecer a história do lado Bessos da minha família que está em Beirute agora, mas também na Escócia e nos Estados Unidos, e a tia que eu tinha na Síria. Vale dizer que há uma comunidade assíria aqui em São Paulo.

Ainda, interesso-me pela civilização de Urartu, que se desenvolveu na atual Armênia, ao longo do lago de Van (atualmente na Turquia) e onde os arqueólogos encontraram grandes fortalezas, cidadelas, e uma delas muito importante perto da capital Yerevan, a cidade de Erebuni, nome antigo, urartiano, da capital que originou Erevan. Então, o que me levou a esse interesse foi ter participado do congresso de Arqueologia Clássica na Turquia acima referido, que aconteceu em Ancara e Esmirna em 1973; e, no Museu de Ancara, eu conheci toda a indústria de metais de bronze da civilização de Urartu, que é uma grande parte do material exposto lá no Museu de Ancara. E, por causa das minhas origens, comecei a ler sobre a civilização de Urartu e me deparei com artigos que falam de empréstimos dessa arte metalúrgica de Urartu pela Grécia no Período Geométrico e pela Etrúria. Há muitas hipóteses sobre esses contatos, o próprio John Boardman, em um livro sobre a Pérsia e o Ocidente, escreve que não acredita que os urartianos tenham tido contato direto com a Grécia e com 
a Etrúria, ${ }^{3}$ mas que esses empréstimos passaram por cidades da Ásia Menor, com as quais gregos e etruscos mantinham contato.

Cheguei a escrever um artigo sobre Urartu, enfim, outro elo que me aproxima do Oriente e das coisas que mais me interessam particularmente no Mediterrâneo antigo (esse artigo fez parte do catálogo de uma exposição sobre arte sacra da Armênia, realizada na Pinacoteca em 2004, "História, Arte e Arqueologia da Armênia. De Urartu a Etchmiadzin", p. 24-35). Depois do congresso na Turquia, eu visitei Chipre, e conheci muito bem Chipre antes dos acontecimentos militares, antes de a ilha ter sido dividida entre parte turca e parte grega. Pude conhecer vários sítios arqueológicos e o Museu de Nicósia, que, com mais experiência numa segunda viagem em 1974, alimentaram mais ainda o meu interesse pela importância de Chipre nessa encruzilhada entre o Mediterrâneo ocidental e o Mediterrâneo oriental.

A última ligação é que, no período em que o Ulpiano foi diretor do museu, eu era a única arqueóloga para o mundo antigo. O Marianno ${ }^{4}$ ainda não tinha chegado, ele estava terminando o seu doutorado em Paris. No museu, não havia regimento, não havia divisão, não havia setor, não havia departamento, não havia nada. Havia coleção. Eu era Chefe do Setor Mediterrânico do MAE e me interessei pelo setor. Quando o Marianno chegou, ele passou a ser o Chefe do Setor Médio-Oriental, incluindo Assiriologia e Egiptologia. Já havia esses acervos no MAE. Quando o professor Marianno faleceu em 1980, pouco depois, eu voltei de um programa de pesquisas de dois anos (França, Síria e Grécia) e o professor Penteado, 5 então diretor do Museu, me designou, por portaria, Chefe do Setor Mediterrânico e Médio-Oriental; então, eu passei a me interessar também pelo futuro do acervo egípcio e acervo mesopotâmico. Formei (com colaboração de egiptólogos do exterior) um Mestre e Doutor em Egiptologia (o prof. Antonio Brancaglion Junior, atualmente com excelente carreira científica no Museu Nacional da UFRJ e no Instituto Francês do Cairo - IFAPO); tentei formar assiriólogos, com apoio de especialistas franceses, porém não tive sucesso; organizei cursos, palestras, mesas-redondas com professores nacionais e estrangeiros dessa área, destacando-se Ciro Flamarion Cardoso (Egiptologia, UFF- Niterói), e os Assiriólogos, Emanuel Bouzon (PUC-RJ), Jean Bottéro (École Pratique des Hautes Études - Paris), Helena Cassin (CNRS-Paris). Como

\footnotetext{
${ }^{3}$ John Boardman. Persia and the West: An Archaeological Investigation of the Genesis of Achaemenid Persian Art. London: Thames \& Hudson, 2000.

${ }^{4}$ Prof. Marianno Carneiro da Cunha, assiriólogo, doutor pela École des Hautes Études en Sciences Sociales, Paris, falecido em 1980.

${ }^{5}$ Prof. Antonio Rocha Penteado, do Departamento de Geografia da FFLCH-USP e um dos diretores do MAE-USP.
} 
remanescente de um programa a mim proposto nessa ocasião por Jean Bottéro, coordenei mais recentemente um programa com os Assiriólogos Jean-Jacques Glassner (CNRS - Paris), Marcelo Rede (FFLCH-USP) e Kátia Pozzer (UFRGS).

HERÓDOTO (H.): A senhora trabalhou em alguns contextos com o renomado arqueólogo francês Paul Courbin, inclusive convidando-o para dar um curso no MAE-USP. Em uma dessas cooperações, participando de escavações lideradas por ele em Ras el Bassit, na Síria. A senhora poderia comentar um pouco dessa colaboração com Paul Courbin e sobre a dinâmica de trabalho nessas escavações?

H.S.: Tive o primeiro contato com Paul Courbin quando fui membro da Escola Francesa de Atenas, entre 1966 e começo de 1969. Eu participei das escavações em Argos, que é um sítio marcado pela presença do Courbin, porque ele praticamente ressuscitou as técnicas de trabalhos de campo para a Escola Francesa de Atenas, praticando a metodologia pregada por Mortimer Wheeler. E o rigor do Courbin marcou toda a arqueologia de Argos, que passou a ser uma verdadeira escola de arqueologia, de técnicas de campo. Nessa ocasião, participei das escavações em Argos com arqueólogos que foram formados pelo Courbin, um deles, que era o diretor de escavações, Francis Croissant. Em duas campanhas nos dois anos que escavei em Argos, no Afrodision e na Ágora, o Courbin esteve presente. Não praticando escavações, mas estudando no museu ${ }^{6}$ o material de suas antigas escavações. Ele escavou nos anos de 1950, quando ele era membro da Escola Francesa, e depois como Secretário Geral da Escola. Foi ele, inclusive, que escavou a região do atual Museu de Argos, uma necrópole com material geométrico extraordinário que ele publicou depois, juntamente com outros achados, em dois volumes. ${ }^{7}$ Foi ele que construiu o Museu de Argos; há até uma rua em Argos com o nome dele.

Eu o conheci e fiquei muito bem impressionada com o rigor do seu trabalho, como ele analisava o material na Reserva Técnica; ficamos muito próximos. Uma vez em São Paulo, em 1976, eu o convidei para dar um curso sobre metodologia de campo e teoria arqueológica, que foi a base do livro Qu'est ce que l'Archéologie? Foi um curso muito bom, havia muitos alunos, era uma época em que os professores falavam a língua original e todos os alunos entendiam, não havia necessidade de tradução.

\footnotetext{
${ }^{6}$ Museu Arqueológico de Argos.

7 Paul Courbin. La Céramique Géometrique de l'Argolide, Vol. 1 et 2. Paris: Éditions E. de Boccard, 1966.
} 
E os nossos contatos ficaram mais estreitos, ele já estava escavando em Ras el Bassit, então eu perguntei a ele se eu poderia participar das escavações, eu teria a possibilidade de um afastamento do museu para um período de dois anos com bolsa do governo francês, uma bolsa especial que não era para estudantes, uma bolsa de pesquisa.

Eu fui e fiquei um ano em Paris, primeiro, e centrada no laboratório de Courbin, na Escola de Altos Estudos. ${ }^{8}$ O laboratório tinha o nome de BEMA - Bureau d'Études des Méthodes Archéologiques. O Courbin já era professor na Escola de Altos Estudos, muito rigoroso, de publicar pouco, mas muito bem, e ele era extremamente sistemático: o apelido dele era "l'homme systhème". No BEMA, eu fiquei durante um ano pesquisando cerâmica, vendo os fragmentos conservados no laboratório, eram alguns fragmentos provenientes de Ras el Bassit, foi o ano letivo de 1978-1979; e também participei das escavações do sítio-escola do Courbin. Isso foi muito importante. No sul da França, em uma localidade denominada Bourg-St.Déol, perto do Grignan, havia um sítio-escola. Eu cheguei a escavar uma quadrícula com o Arno Kern; ${ }^{9}$ ele estava fazendo doutorado em Paris, era aluno do Courbin, e também foi para o sítio-escola. Nós participamos juntos da escavação de uma quadrícula sob a orientação do Paul Courbin. Era um sítio galo-romano. Tinha estratigrafia, técnicas de escavação, preparação de perfis para desenhos, topografia... Enfim, eu fiquei hospedada numa casa de campo do Courbin, perto de Grignan, e nós voltamos para Paris, foi entre março e abril de 1979, fazia muito frio. E, em maio, partimos para a Síria.

A experiência em Ras el Bassit foi extremamente importante, não só por conta da prática de campo, mas também pelos achados. Ras el Bassit é um sítio que se identifica como a Posideion antiga, um entreposto grego mencionado por Heródoto. ${ }^{10}$ Em escavações anteriores, o Courbin tinha encontrado estratos do Bronze Recente, condizente com o que Heródoto diz sobre essa cidade que teria sido criada pelo herói aqueu Anfíloco na volta de Troia. E, depois do Bronze Recente, são marcantes a presença fenícia, cipriota e grega (deve-se registrar aqui uma colonização grega a partir do séc. VII a.C.) além de níveis helenísticos e romanos. Em Ras el Bassit, houve a reunião de cipriotas, fenícios e gregos. As escavações, ali, foram uma verdadeira escola de Arqueologia.

Durante as escavações, cada membro da equipe ficava encarregado por uma quadrícula responsabilizando-se por escavação, topografia,

\footnotetext{
8 École des Hautes Études en Sciences Sociales, Paris.

${ }^{9}$ Arno Kern, arqueólogo, professor da UFRGS e pesquisador sênior do CNPq.

${ }^{10}$ Heródoto III, 91.
} 
desenhos e estudo do material. Nós tínhamos jornadas contínuas, começando às 5 h00 da manhã (levantávamos às 4 h00 e às 5 h00 íamos para o sítio), e escavávamos até às $14 \mathrm{~h} 00 / 14 \mathrm{~h} 30$. Depois do almoço, fazíamos uma paradinha muito rápida, e ficávamos em frente à Apoteca (Reserva Técnica) que o próprio Courbin construiu. Ele construiu tanto a casa que hospedava os arqueólogos quanto a Apoteca, e ficávamos em frente a ela, ao ar livre, em mesas muito longas, cada um estudando o seu material, e fazíamos ali a análise do material, a lavagem, secagem, numeração, descrição, colocação do número do inventário e identificação. $\mathrm{Eu}$ trabalhei com 90 sacos de fragmentos encontrados na minha quadrícula. Eram pequenos sacos de papel desses de mercado, mas nem sempre repletos, tudo dependia da estratigrafia e do local do achado. Foi uma experiência extraordinária e o Courbin se encarregava das escavações mais delicadas e controlava cada uma das quadras, principalmente os achados cerâmicos.

Essa experiência me permitiu conhecer a região de Ras el Bassit, que fica a cerca de 40 quilômetros de Latáquia, e a 10 quilômetros do litoral descendo para Ugarit, que eu conheci bem, inclusive os arqueólogos que escavavam em Ugarit naquela ocasião. A campanha de escavações durou 60 dias, eu emagreci 7 quilos... e era muito magrinha. O Courbin, como bom Chefe de Expedição, levava toda a equipe a excursões pela região, aos domingos. Então, nós conhecemos muito bem Latáquia e Ugarit. Foi nessa época que eu comprei essa cabeça de Ugarit (ver figura 2), que conhecemos Tell Sukas, escavação dinamarquesa com uma sucessão estratigráfica mais completa que Ras el Bassit, passando por outros períodos e também com essa frequentação de fenícios, canaanitas, cipriotas e gregos. Fizemos excursões também a Alepo, infelizmente destruída, conhecemos o Museu de Alepo onde estava o material de Ebla (Tell Mardikh); tivemos o grande prazer de conhecer o rio Eufrates.

Esse meu contato com a Síria, Damasco e as excursões, tudo isso me levou surpreendentemente ao consulado da Síria em São Paulo que me propôs fazer uma exposição fotográfica com o nome "De Ebla a Damasco", e eu aceitei, trouxe essa exposição, nós fizemos naquele anfiteatro da USP, houve um coquetel oferecido pelo consulado sírio; e, na ocasião, eu fiz uma conferência sobre a arqueologia do litoral levantino. Apareceu muita gente, quase toda a colônia sírio-libanesa; e, logo depois, eu fui convidada para repetir essa conferência por um diretor de um centro afro-asiático de Londrina. Eu aceitei, repeti a conferência sobre o litoral levantino de Al Mina até Tell Sukas. Assim, essas foram as consequências das participações que tive nas escavações dirigidas pelo Courbin em Ras el Bassit. 
H.: A senhora apresentou durante sua carreira um grande interesse pela publicação de parte do acervo de Arqueologia do Mediterrâneo do MAEUSP. Quanto ao interesse específico de nossa revista, destacam-se alguns de seus projetos de publicação de objetos do MAE-USP como um relevo funerário de Palmira; um relevo cultual de Mitra Touróctono e a réplica do sarcófago de Ahirom. A senhora poderia apresentar resumidamente esses objetos e comentar um pouco da importância de sua publicação?

H.S.: Vou falar primeiro sobre o relevo cultual de Mitra Tauróctono, sobre o qual já fiz um artigo, que foi publicado inicialmente na Revista de Antropologia, mas muito mal editado (com 57 erros de impressão). ${ }^{11}$ Eu o atualizei e o incluí nos trabalhos que apresentei para o concurso de livre docência. ${ }^{12} \mathrm{O}$ interesse por esses objetos foi sempre relacionado às circunstâncias de minhas viagens. O relevo cultual de Mitra Tauróctono estava na Coleção Bezzi. Guida Bezzi, do Rio de Janeiro, que herdou a coleção do avô, Tommaso Gaudenzio Bezzi, que foi o arquiteto e engenheiro do Museu Paulista, do Museu do Ipiranga. O Ulpiano já tinha tido contato com ela, eu fiz uma viagem ao Rio de Janeiro e, na ocasião, vi esse relevo e o considerei muito importante. Então, eu pedi a ela que ele ficasse no MAE em comodato até vermos se o conseguiríamos comprar. $\mathrm{Na}$ ocasião, eu vi também um pouco de material cerâmico, muitas moedas gregas e romanas; e, ingenuamente, como toda jovem entusiasta, fui à papelaria, comprei papel, algodão, cartões, caixas, uma sacola de mão e embalei tudo e trouxe o material num voo da ponte aérea. Sem seguro, sem nada.

Chegando ao museu, o Ulpiano pediu uma verba para a Fapesp, ${ }^{13}$ e eu fiz um parecer científico; já que, sem interesse científico, a Fapesp não daria verba - o interesse cientifico dessas peças, as pesquisas que poderiam ser feitas - e a Fapesp deu uma dotação suficiente para comprar esse material. Em seguida, em uma das viagens para participar do Comitê Científico para o Lexicon, ${ }^{14}$ de que era membro, conheci Maarten Vermaseren, que foi um grande especialista em mitraísmo e em iconografia mitraica. Ele era o responsável pelo verbete Mitra no LIMC. Conversei com ele sobre o relevo que tínhamos aqui, ele se mostrou interessado, mandei fotografias, descrição, medidas. Ele ficou muito

\footnotetext{
${ }^{11}$ Haiganuch Sarian. Baixo-relevo cultual: Mitra Tauróctono. Revista de Antropologia, vol. 23, 1980, p. 141-59.

${ }^{12}$ Haiganuch Sarian. Arqueologia da Imagem: expressões figuradas do mito e da religião na Antiguidade Clássica. Tese de Livre-Docência. Museu de Arqueologia e Etnologia da USP, 2005, p. 182-191.

${ }^{13}$ FAPESP - Fundação de Amparo à Pesquisa do Estado de São Paulo.

${ }^{14}$ Lexicon = LIMC = Lexicon Iconographicum Mythologiae Classicae.
} 
entusiasmado porque esse relevo era tido como perdido e era conhecido apenas através de desenhos em manuscritos do século XVI, sendo o principal manuscrito conservado em Berlim. Pela importância desse relevo cultual, ele pediu autorização para o publicar. Eu falei com o Ulpiano, que deu a autorização. Mandei outras fotos feitas pela Iolanda Huzak, que fazia algumas fotos para o museu; e ele escreveu o livro Mithriaca IV.15

Ele escreveu esse livro apenas sobre esse relevo mitraico. Depois da publicação, achei interessante publicar em português alguma coisa sobre o relevo de Mitra, não só para o conhecimento no Brasil da existência dessa peça muito importante do MAE, mas também porque o Vermaseren não fez o estudo completo de iconografia. Não era seu objetivo - ele apresentou mais o histórico do relevo desde a coleção mais antiga, os manuscritos em que aparecia. Veio-me assim a ideia de escrever um artigo, uma espécie de resenha aumentada do livro. E, quando preparei o material para o volume da minha Livre Docência, eu resolvi retomar esse artigo com desenhos, fotos e estudo iconográfico mais detalhado, e com bibliografia mais recente.

A importância desse relevo não é apenas histórica, mas também pela própria cena representada, Mitra sacrificando um touro. É um mito de origem indo-irânica que passou pela Mesopotâmia, Oriente Próximo, e, da Ásia Menor, se estendeu por todo o Império Romano; mas passou pela Grécia também. Entretanto, na Grécia, a religião mitraica não teve sucesso nenhum como no mundo romano. O relevo é do século II d.C., e o interessante é que os gregos não assimilaram a religião mitraica, a não ser muito mais tarde, na filosofia neoplatônica, mas muito menos que no Império Romano. Há um texto do Momigliano que, quando trata desse assunto, diz que se Mitra não falava grego, pelo menos falava latim. ${ }^{16}$ Mas, o importante é que o mito mitraico não tinha expressão iconográfica, e só adquiriu essa expressão iconográfica por influência da arte helenística, possivelmente de Pérgamo.

Então, o esquema iconográfico de Mitra sacrificando o touro é o mesmo de Héracles e Teseu combatendo o touro de Creta e o touro de Maratona. As tochas dos servidores de Mitra, Cautes e Cautopates, para cima e para baixo, são típicas da iconografia grega; enfim, toda a arte e a iconografia do mitraísmo que se expandiu pelo Império Romano é de origem grega. É um esquema grego transposto: vindo de um mundo indo-europeu, ele

15 Mithriaca IV: Le monument d'Ottaviano Zeno et le culte de Mithra sur le Célius. Leiden: E.J.Brill,1978.

${ }^{16}$ Arnaldo Momigliano. Os limites da Helenização. Rio de Janeiro: Jorge Zahar Editor, 1991. 
teve esse grande sucesso no mundo romano, nos mistérios de Mitra, as iniciações (até imperadores romanos se iniciaram nesses mistérios). Tudo isso demonstra a excepcionalidade do relevo cultual de Mitra Tauróctono.

O relevo funerário de Palmira é mais interessante ainda. Ele vem da coleção Tapajós Hipp, do Rio de Janeiro. ${ }^{17}$ Tapajós Hipp herdou a coleção Hahn, de um colecionador de Berlim cujo cunhado era conservador e arqueólogo do Museu de Berlim. Esse relevo foi comprado da coleção Tapajós Hipp, e quando o Ulpiano era diretor do museu, ele pensava que, como o próprio Tapajós Hipp tinha dito, a inscrição era em aramaico.

Porém, quando eu participei dos trabalhos do BEMA, o Courbin costumava fazer, antes do começo das escavações - que era praticamente o início das várias campanhas arqueológicas do Ministério das Relações Exteriores (Ras el Bassit era uma missão arqueológica no exterior financiada pelo Ministério das Relações Exteriores, como algumas outras em vários locais no mundo, até no Peru)-, ele oferecia um coquetel, lá no BEMA, para os arqueólogos envolvidos nas escavações na Síria; e, então, foram os arqueólogos de Ugarit, vários outros, incluindo aqueles que estudavam Palmira. Lá, eu conheci o Javier Teixidor, que foi um grande especialista em inscrições semíticas. Eu falei a ele que havia essa inscrição em um relevo de Palmira do acervo do MAE, eu não sabia se era em aramaico ou outra língua. E ele disse que se é um busto funerário, a inscrição deveria se referir à pessoa morta representada no busto. Pediu para que eu mandasse uma foto, o que eu fiz ao retornar a São Paulo. Teixidor descobriu então que esse busto aparecia no corpus das inscrições semíticas de 1948,18 mas com um simples desenho da inscrição que não é muito fiel, e com os dizeres: "lapidis fata ignoramus" (ignoramos o destino dessa pedra, dessa lápide).

Então, ele me escreveu dizendo que era o exemplar que constava no corpus de 1948 e que foi parar no Brasil. Pediu autorização para publicálo, eu falei com o Ulpiano, que de imediato a concedeu. Daí a publicação, no boletim de epigrafia semítica na revista Síria de 1974, de uma foto do relevo que eu tinha mandando para ele e com a transcrição correta da inscrição naquela plaquinha e a inscrição do lado. ${ }^{19} \mathrm{Na}$ verdade, a inscrição é uma fórmula funerária sobre o personagem Malkû. Então é: "Ó Malkû, filho de Oga, ai de mim!" (hélas! na tradução francesa da revista ). Ele datou da segunda metade do século III d.C., e a inscrição

\footnotetext{
17 Pertencente ao colecionador Franz Hermann Edgar Tapajós Hipp.

${ }^{18}$ CIS - Corpus des inscriptions sémitiques II, 4293.

${ }^{19}$ Javier Teixidor. Bulletin d'épigraphie sémitique, 1974. Vol. 51, n. 3, p. 334.
} 
daquela tabuinha é apenas o nome do morto Malkû. Essa correspondência com Teixidor me animou a escrever um artigo sobre esse relevo funerário. Depois das escavações de Ras el Bassit, fui a Palmira e conheci muitos relevos funerários no museu local, visitei a necrópole, os hipogeus, fiz várias fotografias, coletei uma grande documentação que sempre atualizo cada vez que vejo uma nova publicação sobre esculturas de Palmira - recentemente saiu uma publicação do Bounni, que era o diretor de antiguidades no tempo em que escavei em Res el Bassit, em coautoria, sobre os bustos funerários, a escultura funerária palmirense. ${ }^{20}$ Essa inscrição não era em aramaico, era em um dialeto palmirense, uma variação do aramaico.

Finalmente, o sarcófago do rei Ahirom (recentemente fui informada por um especialista que o termo correto é Ahirom e não Ahiram, de Biblos). Eu cheguei a fazer várias viagens ao Líbano e a Beirute por causa de uma parte da minha família, a de minha mãe; e, nas três viagens que fiz, que aconteceram antes da guerra civil, eu vi, no Museu Nacional de Beirute, o original do sarcófago. E logo me interessei pela origem da escrita, pela inscrição no sarcófago. Essa é uma história muito interessante, porque o sarcófago original, que é de calcário, tem restos de pintura e relevos. Ele é do século XIII a.C., mas foi reutilizado no século $X$ a.C. e a inscrição data deste período. É a mais antiga inscrição em alfabeto fenício.

O interesse surgiu na época do professor Eurípides, quando essa réplica veio para o museu. Ele e a Regina, sua esposa, participaram de um evento em Beirute, e lá conheceram o Emir Maurice Chehab (Emir é um título correspondente a Sir), que foi uma figura lendária da arqueologia na Síria. Eu o conheci por causa do LIMC também. Sempre o LIMC! - que agregava quarenta países... Bem, o Eurípedes teve contato com o Emir Maurice Chehab e visitou o Museu Nacional de Beirute guiado pelo Emir. Ele viu o sarcófago exposto numa sala especial do Museu e, em sua Reserva Técnica, havia uma réplica desse sarcófago. Foi então que o professor Eurípides solicitou a sua doação ao governo do Líbano, que o destinou ao MAE. O Eurípedes chegou a publicar um artigo sobre esse sarcófago na Revista de História, que eu tenho. ${ }^{21} \mathrm{E}$ aconteceu o seguinte: a professora Maria Cristina de Oliveira Bruno, Museóloga e atual diretora do MAE, pensou em fazer um cenário expositivo na sala em que a réplica estava, mas seria necessário restaurá-lo, entre outras coisas.

\footnotetext{
${ }^{20}$ Anna Sadurska; Adnan Bounni. Les sculptures funéraires de Palmire. Supplementi alla Rivista di Archeologia, 13. Rome: G. Bretschneider, 1994.

${ }^{21}$ Eurípedes Simões De Paula. O sarcófago do rei Ahiram de Biblos. Revista de História, n. 72, 1967, p. 321-7.
} 
Para o projeto expositivo eu fui chamada a colaborar, fiz pesquisas nas minhas idas à Grécia. Muito antes, eu já havia mandado fazer a moldagem da inscrição do sarcófago. Fiz muitas fotografias em Atenas, inclusive em 2008 com a Ana Luiza (excelente fotógrafa, que participou das minhas escavações em Delos, em 2008), além de fotos de livros antigos sobre o local da escavação onde o sarcófago foi encontrado e a equipe de arqueólogos de Biblos. Enfim, consegui as fotos do sarcófago original, de Beirute, e cheguei a propor cinco painéis fotográficos: 1.Fenícia e fenícios (mapas e fotos); 2 . Biblos e a sua necrópole (planta e fotos); 3. o sarcófago, iconografia (fotos e desenhos); 4. o sarcófago e as inscrições; 5. o alfabeto fenício e a árvore genealógica dos alfabetos ocidentais.

As inscrições são muitos interessantes. No sarcófago está: "Sarcófago feito por Ithoba'al, filho de Ahirom, rei de Gêbal, para Ahirom seu pai, como sua morada na eternidade". E, na tampa: "E se um rei dentre os reis, governador dentre os governadores, guerrear contra Gêbal e deslocar esse sarcófago, que o cetro de seu poder seja quebrado, que caia por terra o trono de sua realeza e que reine a paz sobre Gêbal. Quanto a ele, sua memória se apagará no mundo do além". Trata-se de uma inscrição que não é apenas relevante para a história da escrita no ocidente, é uma grande invenção; mas, seu conteúdo, no campo das práticas funerárias, é extremamente importante. Entretanto, apesar desse grande esforço, a exposição não aconteceu. Mais recentemente, a réplica do sarcófago voltou a ser discutida no MAE, já que precisa de uma nova restauração, antes de se retomar o antigo projeto do cenário expositivo.

H.: A senhora estudou a criação do alfabeto grego no seio de diálogos entre gregos, cipriotas e fenícios. A senhora poderia comentar um pouco esse cenário que proporcionou a criação da escrita alfabética grega?

H.S.: Mais uma vez, o meu envolvimento com peças do MAE. A réplica do sarcófago de Ahirom foi doado pelo governo libanês à Universidade de São Paulo na gestão do Miguel Reale22 e ficou no museu, exposto com uma legenda muito sucinta, e eu tentei melhorar as informações sobre o original. Coincidiu com uma viagem, uma de minhas viagens a Beirute. Eu fui ao museu ${ }^{23}$ e conheci o original do sarcófago, uma peça de calcário, muito bonito, muito bem situado no museu e tem restos de pinturas e relevos, e consegui boas fotos do original e pedi a um restaurador a cópia

\footnotetext{
22 Miguel Reale, professor catedrático da Faculdade de Direito da USP e reitor dessa universidade por duas vezes.

${ }^{23}$ Museu Nacional de Beirute.
} 
em gesso de toda a inscrição. Trata-se, como mencionei acima, de uma inscrição em fenício que é considerada, até agora, a mais completa e a mais antiga inscrição em alfabeto fenício; praticamente é o ponto de partida do alfabeto fenício.

Fui lendo em minhas viagens, além do foco da minha pesquisa principal, nas bibliotecas que frequentei. Sempre tirava um tempo para examinar alguns objetos do museu além da cerâmica, que era o meu objeto de estudo principal. E, além dessa curiosidade sobre o alfabeto fenício, quando eu participei das escavações em Ras el Bassit, tomei conhecimento (no Museu Arqueológico de Damasco) do tablete em cuneiforme, aquele que está ali, ${ }^{24}$ descoberto em Ugarit, que registra o mais antigo alfabeto (séc. XIV a.C.). É um abecedário para a escola, tem trinta sinais, dos quais, vinte e dois originaram o alfabeto fenício.

Antes de participar das escavações em Ras el Bassit, estudei muito a cerâmica de Chipre, aquela do pequeno catálogo do MAE, e entrei em contato também, por conta de minha curiosidade, com dois artigos, um artigo do Courbin sobre fragmentos de um vaso cicládico encontrado em Ras el Bassit, e um artigo do Roger Saidah, que era um arqueólogo libanês muito importante, publicado provavelmente na revista Berytus, uma revista de arqueologia libanesa, sobre a necrópole de Tamburit, perto de Tiro, na qual ele encontrou uma píxide geométrica grega associada, na mesma sepultura, a uma ânfora de fabricação local, mas de estilo cipriota, e o curioso é que essa ânfora porta uma inscrição fenícia indicando o topônimo "Aqmata", que parece ser a origem do conteúdo da ânfora. Aqmata é uma localidade. ${ }^{25}$

\footnotetext{
${ }^{24}$ A professora apontou uma réplica de um tablete com o alfabeto fenício em cuneiforme (ver figura 2).

${ }^{25}$ Roger Saidah. Une tombe de l'Age du Fer à Tambourit. Berytus: Archaeological Studies 25, 1977, p. 135-146; Paul Courbin. Fragments d'amphores Protogéométriques Grecques a Bassit (Syrie). Hesperia 61, 1, 1993, p. 95-113.
} 


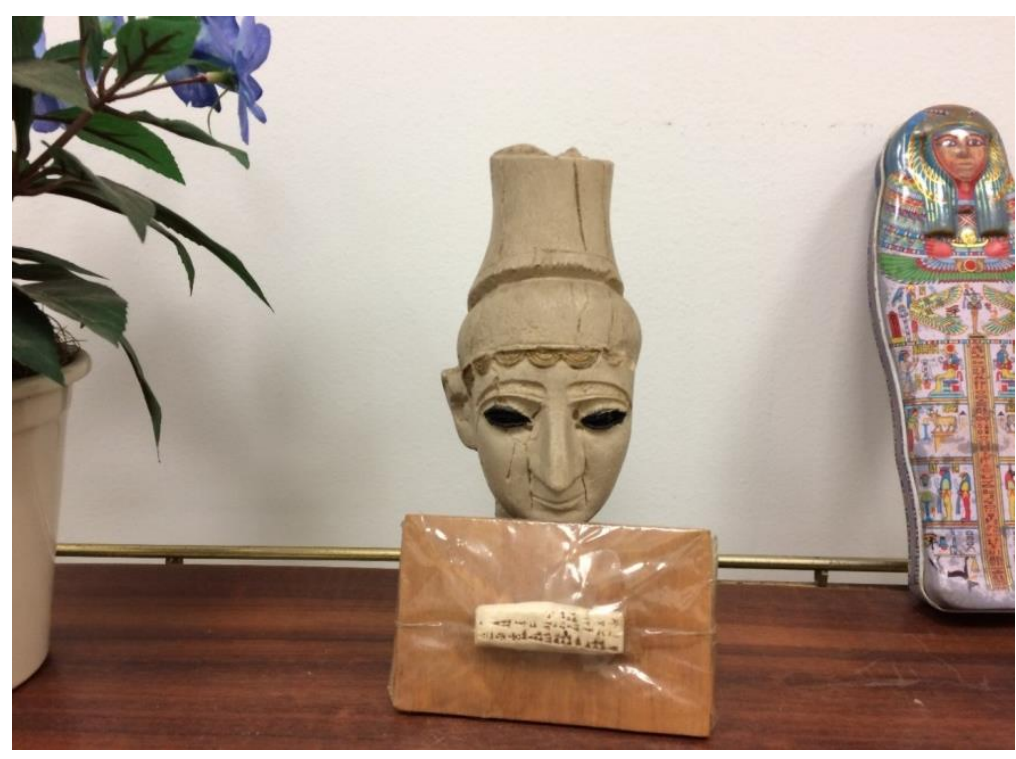

Fig. 2. Sobre uma estante da sala da professora Sarian, as réplicas de uma cabeça de Ugarit e de tablete em cuneiforme, também de Ugarit.

Eu achei muito curioso e comecei a fazer aproximações. Quando nós fizemos a exposição do MAE sobre a escrita alfabética, eu nem me lembro o nome da exposição, mas ela fez muito sucesso; ${ }^{26}$ durante quase um ano, fiz pesquisas sobre inscrições desde o cuneiforme, passando pelo fenício, alfabeto grego, alfabeto etrusco e alfabeto latino, e fui amadurecendo um artigo, o que me deu aproximações muito estreitas não só com esse litoral do Levante, que me pareceu destinado a essa intenção, mas também me levou a Chipre. Eu li um artigo de Jean Irigoin no qual ele chamava atenção para um fato de que não foram os gregos do período chamado de "Renascimento Grego" que inventaram as vogais, que as acrescentaram ao alfabeto fenício, mas que essas vogais vinham do micênico, da conotação do micênico em linear $B$, e essa escrita linear $B$, que é decorrente do linear A cretense, desapareceu na Grécia continental, mas ela sobreviveu em Chipre até período bastante recente, século III a.C.; e ela servia para conotar não só expressões gregas, a língua grega, mas para conotar a língua local autóctone que era o eteocipriota.

Eu fiz imediatamente a aproximação, e me deparei com a referência da Jeffery, ${ }^{27}$ de que o alfabeto grego devia ter surgido em uma área cultural, onde circulavam gregos, cipriotas e fenícios. Então, a charada estava esclarecida. Eu estudei as relações da Grécia, Chipre e do litoral levantino, desde a Cilícia, Tarso, Al Mina, passando por Ras el Bassit,

\footnotetext{
26 Trata-se da exposição de 1998: "A Escrita do Mundo Antigo".

${ }^{27}$ Lilian H. Jeffery. The local scripts of archaic Greece. A study of the origin of Greek alphabet and its development from the eighth to the fifth centuries B.C. Oxford: Clarendon Press, 1961.
} 
onde muito material grego foi encontrado, inclusive esses fragmentos cicládicos que o Courbin publicou; e, depois, descendo no litoral, pouco abaixo, Ugarit com o tablete, mais embaixo até Tell Sukas, também com material grego e cipriota; então, é possível perceber em todo o litoral fenício, descendo para a região do atual Líbano, Biblos e, perto de Biblos, o sarcófago de Ahiram com a primeira grande inscrição, e Tiro, onde, nas proximidades, a localidade de Tamburiti, existem três remanescentes culturais da Grécia, de Chipre e da Fenícia associados numa mesma sepultura.

Esse foi o itinerário da pesquisa, vai daí que há também um antecedente da escrita fenícia na região do Monte Sinai, a escrita protossinaítica, onde era uma região frequentada pelos egípcios, com muitas inscrições hieroglíficas, mas há também muitas inscrições fenícias, quer dizer, com sinais próximos aos sinais que posteriormente registaram o fenício. E era uma região de frequentação de mercadores. É muito provável então que mercadores egípcios fossem a essa região do Sinai em busca daquela pedra preciosa turquesa que aparece em muitos objetos fabricados no período faraônico, e é possível que mercadores levantinos também tivessem frequentado essa região e deixado as inscrições em cerca de 1600 a.C., que parecem estar na origem do abecedário ugarítico e do alfabeto fenício registrado no sarcófago do rei Ahirom.

H.: Professora Haiganuch Sarian, a senhora é uma grande especialista nos estudos iconográficos. Entre os vários temas que vem estudando, o empréstimo iconográfico é um deles, como notado no caso da iconografia das Erínias na Grécia e na Etrúria. Outro empréstimo que chama a atenção é aquele que estruturou a criação do esquema iconográfico de Perseu decapitando a Górgona. A senhora poderia apresentar essa pesquisa e dizer como ela explicita algumas relações entre mundo grego e "Oriente"?

H.S.: A questão dos empréstimos de esquemas iconográficos sempre me preocupou nos muitos estudos que fiz, e acho que há muita coisa a ser pesquisada e publicada sobre esse tema. O artigo sobre as Erínias na Grécia e na Etrúria foi publicado nas atas de um colóquio que o programa do Lexicon organizou. O colóquio foi em Paris em 1983 e foi publicado no $\mathrm{BCH}$, suplemento catorze. ${ }^{28}$ Nesse volume, há vários capítulos: Grécia,

\footnotetext{
${ }^{28}$ Haiganuch Sarian. Réflexions sur l'iconographie des Érinyes dans le milieu grec, italiote et étrusque. In: Actes du Colloque International du CNRS no.619/Paris, 1983, Paris. Iconographie Classique et Identités Régionales. Atenas/Paris : École Française d'Athènes, 1986. p. 25-35.
} 
Roma, Etrúria e, depois, regiões periféricas. No entanto, eu tive a ideia de explorar o tema das Erínias a partir da Grécia até a Etrúria e tentei, com alguns orientandos, dar sequência a essa linha de pesquisa, mas não deu certo. Realmente, precisa de muita erudição e eu pensei em temas da iconografia grega explorados no meio italiota e depois indo até a Etrúria e até os sarcófagos romanos.

O mesmo tema de empréstimo, Perseu decapitando a Górgona, surgiu de uma experiência em sala de aula. Dando uma aula sobre o lécito ático do MAE, onde há a representação de Perseu fugindo com a cabeça da Górgona, eu comecei a explorar esse esquema iconográfico e cheguei a conclusões interessantes, que depois eu expus em outra aula, e por fim, transformei em pesquisa. Acumulei uma boa bibliografia sobre o assunto, algumas fotos e tudo isso eu tenho numa pasta e ainda não tive tempo de arregaçar as mangas e estudar com cuidado toda a bibliografia e publicar esse estudo. Na verdade, a conclusão a que cheguei, e que já aparece em alguns títulos bibliográficos, é que a cabeça da Górgona, isto é, o Gorgoneion, é mencionado tanto nos textos literários quanto na iconografia antes do episódio de Perseu decapitando a Górgona. As imagens do Gorgoneion remontam ao período minoico na Grécia. Há máscaras que lembram bem a máscara da Górgona, do mesmo modo que há máscaras na região da Síria, região mesopotâmica, que lembram a máscara de Humbaba, que é uma figura mitológica da Babilônia. E então eu fiz um paralelo.

Depois, comecei a examinar essas máscaras mesopotâmicas que aparecem em cilindros-selos, e comecei a estudar a iconografia mesopotâmica, os cilíndros-selos, e vi o esquema de uma figura masculina com o rosto frontal, mas o corpo virado à esquerda, decapitando um animal, uma figura de animal. Esse esquema depois evolui para um esquema mais aperfeiçoado que aparece na Síria por volta do século VIII a.C., em que a figura masculina segura a harpe, aquela foice que aparece na iconografia de Perseu na Grécia, decapitando um monstro cuja face é uma máscara, o que é interpretado como Gilgamesh decapitando Humbaba, episódio esse conhecido na Epopeia de Gilgamesh. Então eu teria que reunir vários testemunhos, eu não tive tempo ainda para isso. Mas o mais interessante é que, de um lado, há a civilização assíria, do norte da Síria; e, de outro lado, o mundo grego.

Vasculhando a bibliografia, eu encontrei um cilindro-selo de Chipre do século VII a.C., e que está atualmente em Berlim, onde o esquema Iconographicum Mythologiae Classicae. 1 ed. Zurique: Artemis Verlag, 1986, v. 3, p. 825-843. 
iconográfico é exatamente o mesmo e a interpretação é duvidosa - alguns autores falam em Gilgamesh decapitando Humbaba e outros autores falam de um dos mais antigos esquemas de Perseu decapitando a Górgona. Eu acho que é Perseu decapitando a Górgona por causa da localidade, Chipre, onde havia elementos de aproximação com a Grécia, com o mundo grego, muito mais do que com o mundo mesopotâmico. E, então, eu fiz um esquema, um itinerário de artigo mostrando que o episódio de Perseu decapitando a Górgona é mencionado em Hesíodo (Teogonia, 276-280) mas não em Homero. Em Homero temos o Gorgoneion apenas. Ora, a Teogonia de Hesíodo tem origens na cosmogonia mesopotâmica. Daí uma série de coincidências: há Hesíodo, a Teogonia; há o episódio de Perseu decapitando a Górgona em Hesíodo; há o cilindroselo de Chipre no mesmo período e que eu interpreto como Perseu decapitando a Górgona.

Com esses dados, cheguei à conclusão provisória de que o episódio de Perseu decapitando a Górgona é originário da figuração transmitida do oriente para o mundo cipriota e grego. E não é sem razão que isso acontece no chamado período orientalizante. Então, esse assunto fecha realmente um itinerário de ideias. Eu cheguei a fazer uma conferência em um dos congressos da SBEC $^{29}$ realizado em Araraquara, não me lembro bem do ano, em que o título era " A aventura orientalizante na Grécia", em que eu explorei as publicações do Ekrem Akurgal, La naissance de l'art grec, os estudos que ele fez da aproximação da Âsia Menor com a arte grega nesse período, explorei o Boardman e uma peça do MAE, uma cabeça de koûros, e terminei a conferência falando exatamente dessa questão do empréstimo do esquema iconográfico de Gilgamesh decapitando a cabeça de Humbaba e de Perseu decapitando a Górgona.

Sobre a cabeça de koûros do MAE, que é uma escultura cipriota e que me levou a pesquisar a escultura arcaica em Chipre, ela é muito devedora da escultura assíria: a frontalidade, o penteado dos cabelos, muito próxima da escultura assíria contemporânea a ela. E conversando com um colega que foi membro suíço da Escola Francesa de Atenas, Rolf Stucky, mostrei a foto da escultura do MAE para ele, que estava escavando no litoral do Líbano, uma escavação particular de uma missão suíça muito efêmera em Biblos, e ele disse: "ah, interessante, lá no templo de Eshmum foi encontrada uma cabeça de koûros muito parecida que está no Museu Nacional de Beirute". Então, muito por baixo, ele conseguiu a foto e, para mim, realmente parece que são duas esculturas saídas do mesmo escultor. E é muito provável que essa cabeça do MAE provenha de Eshmum, do templo de Eshmum, em Biblos.

\footnotetext{
${ }^{29}$ Sociedade Brasileira de Estudos Clássicos.
} 
Ela está muito restaurada, foi feito um exame de raio-X. Aliás, a Bia e a Mabel, ${ }^{30}$ há muitos anos, levaram essa cabeça a um hospital aqui da universidade para um raio- $X$, e é possível ver a restauração, onde há muitos pregos. Mas há o essencial para ver o estilo original, e para comparar com a segunda cabeça que está em Beirute. E é interessante que essa cabeça de koûros foi comprada de uma coleção do Rio de Janeiro no tempo da gestão do Ulpiano, a coleção Tapajós Hipp, da qual muita coisa veio para o setor egípcio do MAE. Tapajós Hipp herdou a sua coleção da antiga coleção Hahn de Berlim, e o colecionador Hahn tinha um cunhado que era conservador do Museu Arqueológico de Berlim. Então, eu acho que, por orientação do seu cunhado, Hahn adquiriu essa cabeça possivelmente de uma região não distante do Líbano, por causa do segundo exemplar encontrado no templo de Eshmum. Mais uma vez, o meu envolvimento com Chipre e o meu envolvimento com o litoral levantino.

H.: Professora Sarian, a senhora vem dirigindo, nas últimas décadas, as escavações de um sítio arqueológico situado na ilha de Delos, o Heraion (o santuário de Hera). Esse santuário, um dos mais antigos da ilha, teve como vizinhos santuários relacionados a divindades egípcias como Ísis e Serápis. A senhora poderia comentar algo das escavações do Heraion, seus achados e as circunstâncias de aproximação desses cultos (gregos e egípcios) no período helenístico?

H.S.: Comecei realmente a pesquisar o Heraion de Delos em 2000, apesar de ter recebido essa responsabilidade bem antes, o que começou com um dossiê cerâmico que Olivier Picard, então diretor da escola (EFA), me encarregou de estudar a cerâmica do Heraion e renovar a publicação do Dugas. ${ }^{31}$ Eu fiquei seis anos sem ir à Grécia, e quando eu fui em 1996, tive uma conversa séria com Roland Étienne, que era diretor da escola na ocasião, falei com ele que eu tinha refletido um pouco sobre o projeto e que achava que estudar a cerâmica desvinculada do santuário não seria muito interessante, e que a minha preocupação maior sempre tinha sido o estudo de unidades arqueológicas, eu queria tratar do santuário de Hera na sua totalidade, estudando não só os templos, mas fazendo prospecções e estudando o material publicado nos anos 1920 e 1930 do século passado. Ele concordou, repeti essa conversa com Phillip Bruneau, ele achou

\footnotetext{
30 Maria Beatriz Borba Florenzano e Maria Isabel d'Agostino Flemming, respectivamente, líderes dos laboratórios LABECA (Laboratório de Estudos sobre a Cidade Antiga) e LARP (Laboratório de Arqueologia Romana Provincial), ambos sediados no MAE-USP.

31 Charles Dugas. Les Vases de l'Héraion. Exploration Archéologique de Délos 10. Paris: E. De Boccard, 1928.
} 
excelente e, como argumento, eu me apoiei nas sondagens que tinham sido feitas entre a primeira escavação em 1911, por Pierre Roussel, e em 1958, uma sondagem por Paul Bernard, e em 1964, uma sondagem por Jean Ducat. Essas sondagens foram muito limitadas, uma semana de escavação, mas elas deram bom resultado porque eram pistas para continuação das escavações.

Resumidamente, nas escavações originais no período da grande fouille da Escola Francesa de Atenas, foram descobertos os dois templos no santuário de Hera, um mais antigo embutido na cela do mais recente e um depósito votivo de importância extraordinária, muito volumoso, com material cerâmico publicado por Charles Dugas em 1928, e as estatuetas de terracota e os prótomes de terracota publicados pelo Laumonier em 1956,32 eu acho; e, em 1928, no mesmo ano da publicação de Charles Dugas, Plassart publicou o volume sobre os santuários e os cultos da região do Monte Cinto, ${ }^{33}$ e incluiu um longo capítulo sobre o Heraion, não só a parte arquitetônica, o altar, mas também alguns achados.

O interessante é que eu não pude seguir um programa de escavações, de sondagens; não foram escavações sistemáticas, por falta de infraestrutura. Por exemplo, em 2000, o trabalho foi feito apenas com material cerâmico e, então, nós estudamos principalmente fragmentos da primeira escavação que não tinham sido publicados; e estudamos os achados da sondagem de Jean Ducat e Paul Bernard. Em 2002, eu fiz a primeira escavação, e tinha objetivos precisos para esclarecer a chamada eskhára, aquela espécie de bóthros, construída adjacente ao altar; foi recuperado o conjunto de fragmentos que compunham essa pequena construção e o interior da cela, o interior do pronáos e a ligação do templo mais recente com o muro de arrimo do terraço dos templos.

Em todas essas, nos setores A, B, C e D dessas escavações, eu encontrei um bom número de material helenístico, e esse material helenístico me fez suspeitar de uma frequentação do santuário também no período helenístico, algo que só se conhecia através de inscrições, os inventários de Delos. Arqueologicamente não havia quase nada, a não ser o altar (o altar realmente é de 305, do período helenístico). E, depois, uma segunda campanha foi realizada na entrada do santuário em 2006 (aliás, você, Gilberto, participou desta e da campanha de 2008, sendo que em 3 outras apenas trabalhamos na Reserva Técnica); na campanha de 2006 na entrada do santuário, confirmou-se a sua frequentação no período

\footnotetext{
32 Alfred Laumonier. Les figurines de terre cuite, 2 vol. Exploration Archéologique de Délos 23. Paris: E. De Boccard, Paris, 1956.

${ }^{33}$ André Plassart. Les sanctuaires et les cultes du mont Cynthe. Exploration Archéologique de Délos 11. Paris: E. De Boccard, 1928.
} 
helenístico. E, finalmente, a campanha de 2008, que foi a continuação da sondagem de Jean Ducat, ligando a sondagem de Jean Ducat com a sondagem de Paul Bernard, é que foi possível registrar mais do que tudo uma frequentação no Período Geométrico, muito importante.

Na campanha de 2008, foi o material geométrico o mais excepcional; nas camadas superiores, um pouco de material helenístico, mas enfim, com essas três campanhas e com as observações no museu ${ }^{34}$ sobre o material existente das primeiras escavações e das duas sondagens feitas posteriormente, e sobretudo observando o material do depósito votivo, foi possível obter uma cronologia que não condiz muito com a cronologia até agora estabelecida. Na publicação de Plassart e no Guide de Délos ${ }^{35}$ há uma insistência em indicar o início da vida cultual do Heraion a partir da primeira metade do século VII até 500 a.C. mais ou menos, época de Leagros. Foi dada uma pequena informação sobre o resultado da sondagem de Jean Ducat, mas sem insistir na cronologia do primeiro templo.

A minha conclusão, que precisa ainda de algumas confirmações, é que o Heraion, o santuário como um todo, teve o início da vida cultual com um pequeno templo da segunda metade de século VIII a.C., do Período Geométrico, depois embutido na cela do segundo templo mais recente. Isso não só as escavações de 2008 confirmaram, como alguns fragmentos geométricos, alguns vasos e aquelas réplicas de romãs que são do geométrico recente também, e que foram encontrados no depósito votivo e que não foram suficientemente aproveitados para o estabelecimento da cronologia inicial no Heraion. E, depois, o período final de construção do segundo templo é mais recente do que se imaginava; é o que indica a análise de material cerâmico mais recente do depósito votivo que é de cerca de 480 a.C. e não 500 a.C.

Esse já é um bom resultado para a compreensão da frequentação do santuário; mas o importante é assinalar que temos uma lacuna muito grande entre o primeiro quartel do século V a.C. e a época helenística, que corresponde ao período da independência de Delos, entre 314 e 167 a.C. Ora, este é o período em que surgem nesse terraço, justamente denominado "o terraço dos deuses estrangeiros", os santuários egípcios e também o sírio. Na história de Delos, isso não explica a ausência de frequentação do Heraion no período clássico, o que é uma grande questão, uma grande dúvida que, no meu entender, pode estar relacionada com

\footnotetext{
${ }^{34}$ Museu Arqueológico de Delos.

${ }^{35}$ Plassart, Op. cit.; Philippe Bruneau \& Jean Ducat. Guide de Délos. 4èmme éd. Paris; Athènes: E. De Boccard, 2005.
} 
um novo estudo da cronologia do templo de Zeus e Atena no monte Cinto. Se eu tivesse mais tempo, examinaria o material encontrado nesse templo, porque parece que o sucesso do templo de Zeus e Atena obscureceu um pouco, no período clássico, a frequentação do templo de Hera. Então, haveria uma lacuna na frequentação do Heraion no período clássico, substituída pelo sucesso do santuário de Zeus e Atena no Cinto.

Mas, no período helenístico, o que acontece em Delos é um aumento da população estrangeira por razões comerciais, mercantis. Delos era um porto muito importante entre o litoral do Próximo Oriente levantino e a Itália; então, muitos mercadores iam a Delos, viviam em Delos e construíam também santuários aos seus deuses, que são muito numerosos nessa ilha. Na vizinhança do Heraion, há o Sarapieion B, mas foram construídos três santuários dedicados a Serápis nas proximidades do rio Inopos e do terraço do Heraion, o Sarapieion A e C, e também o templo de Ísis que coteja o santuário de Hera. Não há relação direta entre as divindades. Mas o renascimento dessa região com os cultos estrangeiros fez consequentemente renascer o culto de Hera, tanto que se erigiu um altar nesse período, a frequência no período helenístico é maior, as inscrições falam de cuidados com a estátua de Hera, de remanejamento no teto, de pínakes que eram consagradas no templo. Então, eu acredito em um renascimento religioso nessa região, e o santuário de Hera foi influenciado pelo florescimento destes cultos egípcios; tanto que o grande muro de arrimo do terraço do santuário de Hera foi remanejado no período helenístico prolongando-o e servindo, ao mesmo tempo, de limite para o santuário de Serápis.

Assim, não vejo relação cultual, mas vejo um florescimento muito grande dessa região, nesse terraço e mais embaixo perto do Inopos; e, em consequência, um renascimento no culto de Hera. Isso sem contar com o acaso das escavações, já que o grande terraço do Heraion não foi inteiramente escavado, e eu não sei se um dia será encontrado algum material do período clássico; é sempre o estado atual da questão.

H.: Nesse mesmo santuário de Hera em Delos, as pesquisas arqueológicas que dirige (escavações e análise laboratorial) vêm mostrando uma grande quantidade de cerâmica orientalizante produzida por oficinas da "Grécia de Leste". A senhora poderia comentar a situação desses achados e como eles interferem na interpretação da cronologia do culto de Hera em Delos? 
H.S.: A questão da cronologia não é muito importante na datação destes dois templos, porque os vasos da Grécia de Leste do Heraion provêm do depósito votivo. Os grandes achados nas escavações que dirigi não estão relacionados a material tão representativo da Grécia de Leste. Na verdade, trata-se de material cerâmico da favissa do santuário, todo ele do século VII e VI a.C., importante do ponto de vista da cronologia apenas porque revela uma frequentação do local consistente nesse período. Há excelente material de Rodes, como, por exemplo, o estilo das "cabras selvagens"(wild goat style); de Quíos, representado por exemplares de cálices magníficos; do norte da Jônia; de Náucratis no Egito. São esses alguns dos centros que produziram vasos que nós encontramos no Heraion.

Do ponto de vista da cronologia, é sempre séculos VII e VI a.C.; entretanto, o problema maior não é tanto a cronologia, mas como esses vasos chegaram até o Heraion. Qual o tipo de frequentação? Seriam fiéis vindos da Jônia ou esses vasos vieram de centros intermediários e foram levados por fiéis cicládicos. É uma questão muito complicada e ela não é exclusiva do Heraion e de Delos, levando-se em conta o rico material semelhante descoberto por John Boardman em suas escavações também em Quíos e em Tocra (Cirenaica, Líbia). Ora, alguns achados são muito volumosos, por exemplo, os de Rodes. Só daqueles chamados por Dugas de vases-couronnes (que são, na verdade, askói), há em torno de 30 exemplares. Então, no caso particular do santuário de Hera, esses vasos eram exportados da Grécia de Leste para as Cíclades e adquiridos por pessoas que habitavam Delos ou locais próximos da ilha de Delos que os levaram e ofertaram à deusa Hera ou seu santuário era frequentado por jônios devido à grande importância do santuário de Apolo? É uma questão deliana, não só uma questão do Heraion. 